\title{
Footprinting with MPE $\cdot$ Fe(II). Complementary-strand Analyses of Distamycin- and Actinomycin-binding Sites on Heterogeneous DNA
}

\author{
M.W. VAN DYKE AND P.B. DERVAN \\ Division of Chemistry and Chemical Engineering, California Institute of Technology, Pasadena, California 91125
}

We recently reported a direct technique for determining the binding sites of small molecules on naturally occurring heterogeneous DNA (Van Dyke et al. 1982). Methidiumpropyl-EDTA·Fe(II) (MPE·Fe[II]) (Hertzberg and Dervan 1982) cleaves double-helical DNA with low sequence-specificity (Van Dyke et al. 1982). Using a combination of $\mathrm{MPE} \cdot \mathrm{Fe}(\mathrm{II})$ partial cleavage of drugprotected DNA fragments and Maxam-Gilbert sequencing methods, we determined the drug-protected sites on one strand of a double-helical fragment from pBR322 for the intercalator actinomycin D (Goldberg et al. 1962; Muller and Crothers 1968; Wells and Larson 1970; Sobell 1973; Krugh 1981; Patel et al. 1981; Takusagawa et al. 1982) and the minor-groove binders netropsin and distamycin A (Luck et al. 1974; Wartell et al. 1974; Zimmer 1975; Berman et al. 1979; Krylov et al. 1979). Netropsin and distamycin A gave identical DNA-cleavage inhibition patterns or footprints in regions rich in $\mathrm{dA} \cdot \mathrm{dT}$ base pairs. Actinomycin $\mathrm{D}$ afforded a completely different footprint pattern centered around one or more $\mathrm{dG} \cdot \mathrm{dC}$ base pairs (Van Dyke et al. 1982). (See Fig. 1 for structures of MPE $\cdot \mathrm{Fe}[\mathrm{II}]$, actinomycin D, and distamycin A.)

We are not certain whether there is a one-to-one correspondence between a protected region on one strand of the double-helical DNA fragment and the drugbinding site on the DNA. We presume that the reaction responsible for DNA strand scission by MPE-Fe(II) is an oxidative cleavage of the deoxyribose ring analogous to mechanisms postulated for bleomycin activity (Hecht
1979; Burger et al. 1981). The different accessibility of adjacent deoxyribose rings to the propyl-EDTA-Fe(II) moiety in the unprotected site bound by MPE might result in asymmetric footprints on opposite DNA strands. From model building with right-handed, double-helical DNA and MPE-Fe(II), we expect the footprint on each DNA strand to be shifted at least $1 \mathrm{bp}$ to the $3^{\prime}$ side of the drug-binding site (Fig. 2). Greater precision in identifying the boundaries of the preferred drug-binding sites would be afforded by an analysis of opposite strands.

We report here complementary-strand analyses of distamycin and actinomycin binding on heterogeneous DNA using the MPE· $\mathrm{Fe}$ (II) footprinting technique. Two DNA restriction fragments, $117 \mathrm{bp}$ and $168 \mathrm{bp}$ in length, each containing regions of identical sequence, were prepared with $3^{\prime}$-end labeling on complementary strands. DNA-cleavage inhibition patterns resulting from $\mathrm{MPE} \cdot \mathrm{Fe}$ (II) cleavage of the drug-protected DNA restriction fragments provide the opposite-strand footprints (Fig. 3). This affords a more precise location of the preferred binding sites on $50 \mathrm{bp}$ of heterogeneous DNA for distamycin and actinomycin.

\section{MATERIALS AND METHODS}

Actinomycin D was obtained from Merck, Sharpe, and Dohme. Distamycin A was obtained from Boehringer Mannheim. Dithiothreitol (DTT) was obtained from

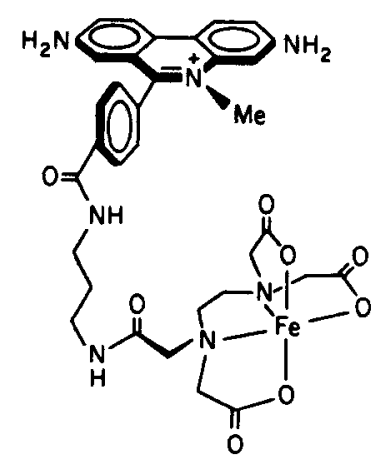

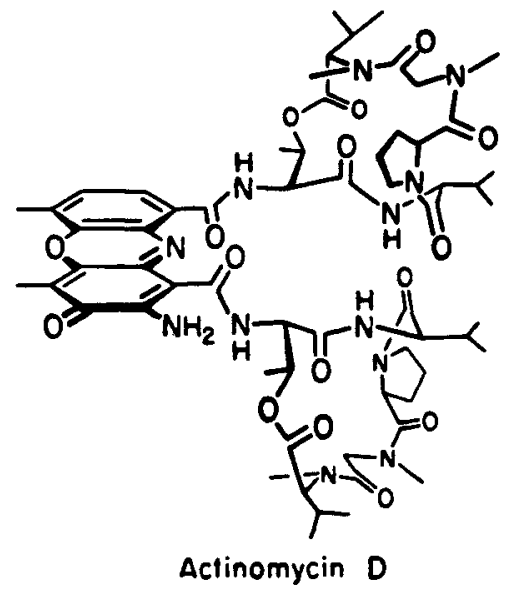

Actinomycin D<smiles>[CH2-][NH2+]CCNC(=O)c1cc(NC(=O)c2cc(NC(=O)c3cc(NC=O)cn3C)cn2C)cn1C</smiles>

Distomycin $A$

Figure 1. Methidiumpropyl-EDTA $\cdot F e(I I)$, actinomycin, and distamycin. 


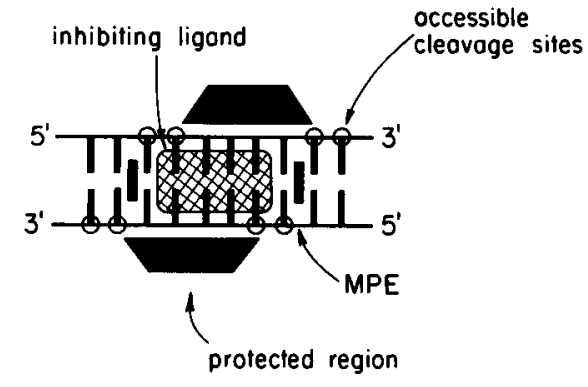

Figure 2. Model for asymmetric footprint.

Calbiochem. Ferrous ammonium sulfate, $\mathrm{Fe}\left(\mathrm{NH}_{4}\right)_{2}-$ $\left(\mathrm{SO}_{4}\right)_{2} \cdot 6 \mathrm{H}_{2} \mathrm{O}$, was obtained from Baker. MPE was synthesized and purified by procedures already described (Hertzberg and Dervan 1982). The plasmid pLJ3, constructed by L. Johnsrud (Harvard University), was a generous gift from D. Galas (University of California, Los Angeles).

Solutions of $\mathrm{Fe}\left(\mathrm{NH}_{4}\right)_{2}\left(\mathrm{SO}_{4}\right)_{2} \cdot 6 \mathrm{H}_{2} \mathrm{O}$, DTT, and MPE were freshly prepared. Concentrations of MPE, actinomycin, and distamycin were determined spectroscopically. Reactions ( $10 \mu \mathrm{l}$ final volume) contained 10 $\mathrm{mm}$ Tris- $\mathrm{HCl}(\mathrm{pH} \mathrm{7.8)}$ and $50 \mathrm{~mm} \mathrm{NaCl}$. Each reaction mixture contained more than $600 \mathrm{cpm}$ of DNA labeled on the $3^{\prime}$ end with ${ }^{32} \mathrm{P}$, and the final concentration of DNA base pairs was brought up to $100 \mu \mathrm{M}$ by the addition of sonicated, deproteinated calf thymus DNA. When present, final concentrations were $10 \mu \mathrm{M}$ MPE, $10 \mu \mathrm{M} \mathrm{Fe}(\mathrm{II})$, and $4 \mathrm{~mm}$ DTT. Actinomycin and distamycin concentrations were adjusted (1-100 $\mu \mathrm{M})$ as specified in Figure 5. For footprinting, a solution of buffered DNA was incubated for 30 minutes at $20^{\circ} \mathrm{C}$ with either actinomycin or distamycin. The reaction was initiated by the addition of MPE.Fe(II) followed by DTT. The reaction was allowed to run at $37^{\circ} \mathrm{C}$ for 15 minutes, stopped by freezing in dry ice, and then lyophilized and resuspended in formamide loading buffer for gel electrophoresis (Maxam and Gilbert 1980).

Preparation of specific, labeled DNA fragments. DNA for this investigation consisted of a sequenced segment of the lactose operon in Escherichia coli. This was isolated from the plasmid pLJ3 grown in $E$. coli strain MM294. Part of this plasmid is a 285-bp insert containing two copies of the lactose operon promoter-operator sequence in the same orientation. A schematic diagram of the insert is shown in Figure 3. Milligram quantities of the plasmid were isolated by procedures similar to those of Tanaka and Weisblum (1974). Superhelical pLJ3 plasmids were first digested with the restriction endonuclease $E c o$ RI and then labeled on the $3^{\prime}$ end with $\left.{ }^{32} \mathrm{P}\right] \mathrm{dATP}$ and the Klenow fragment of DNA polymerase I. A second enzymatic digest with the restriction endonuclease HaeIII yielded two end-labeled fragments, $117 \mathrm{bp}$ and $168 \mathrm{bp}$ in length. These were isolated by gel electrophoresis on a 5\% polyacrylamide, 1:30 crosslinked, 4-mm-thick preparatory gel. Further recovery and purification followed procedures similar to those of Maxam and Gilbert (1980).

Sequencing gels. Resolution of inhibition patterns was achieved by electrophoresis on $8 \%$ polyacrylamide, $1: 20$ cross-linked sequencing gels that were $0.4 \mathrm{~mm}$ thick, $40 \mathrm{~cm}$ long and contained $50 \%$ urea. Electrophoresis was carried out at $1000 \mathrm{~V}$ for 3.5 hours to sequence 100 nucleotides, beginning 20 nucleotides from the labeled $3^{\prime}$ end. Autoradiography was carried out at $-50^{\circ} \mathrm{C}$ without the use of an intensification screen.

Densitometry. An $8 \times 10$-inch copy of the original autoradiograph was scanned at $485 \mathrm{~nm}$ with the incident beam collimated to a width of $0.05 \mathrm{~mm}$ on a Cary 219 spectrophotometer. The data were recorded as absorbance relative to the film-base density and analyzed using an Apple microcomputer.

\section{RESULTS}

For an investigation of the sequence-specific DNAcleavage inhibition by actinomycin and distamycin with MPE.Fe(II), two DNA substrates were prepared. The 117 -bp and 168 -bp restriction fragments, each containing the lactose operon promoter-operator region, were prepared with the $3^{\prime}$ ends labeled with ${ }^{32} \mathrm{P}$ on complementary strands. MPE-Fe(II)/DTT was allowed to react with the 117-bp or 168-bp fragments alone (Fig. 4) and with the 117-bp or 168-bp fragments preequilibrated with either actinomycin or distamycin (Fig. 5). Partial cleavage by MPE-Fe(II) was stopped after 15 minutes by freezing, lyophilization, and resuspension in formamide buffer. The ${ }^{32} \mathrm{P}$-end-labeled DNA products were analyzed by denaturing $8 \%$ polyacrylamide $/ 50 \%$ urea gel electrophoresis, which is capable of resolving DNA fragments differing in length by one nucleotide. The autoradiographic data are shown in Figures 4 and 5.

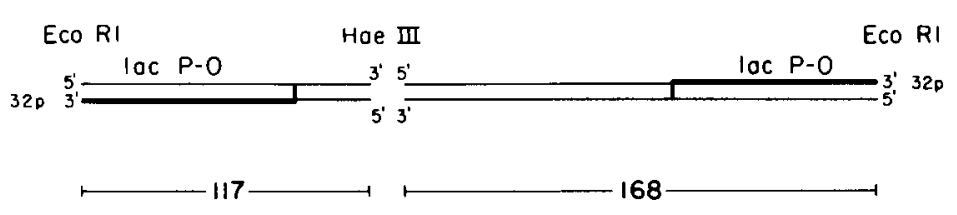

Figure 3. Schematic diagram of 117-bp and 168-bp fragments derived from cleavage of 285 -bp $3^{\prime}$-endlabeled fragment with the restriction enzyme HaeIII. The 117-bp and 168-bp fragments each contain one copy of the lactose operon promoteroperator region with complementary-strand, $3^{\prime}$-end labeling. 


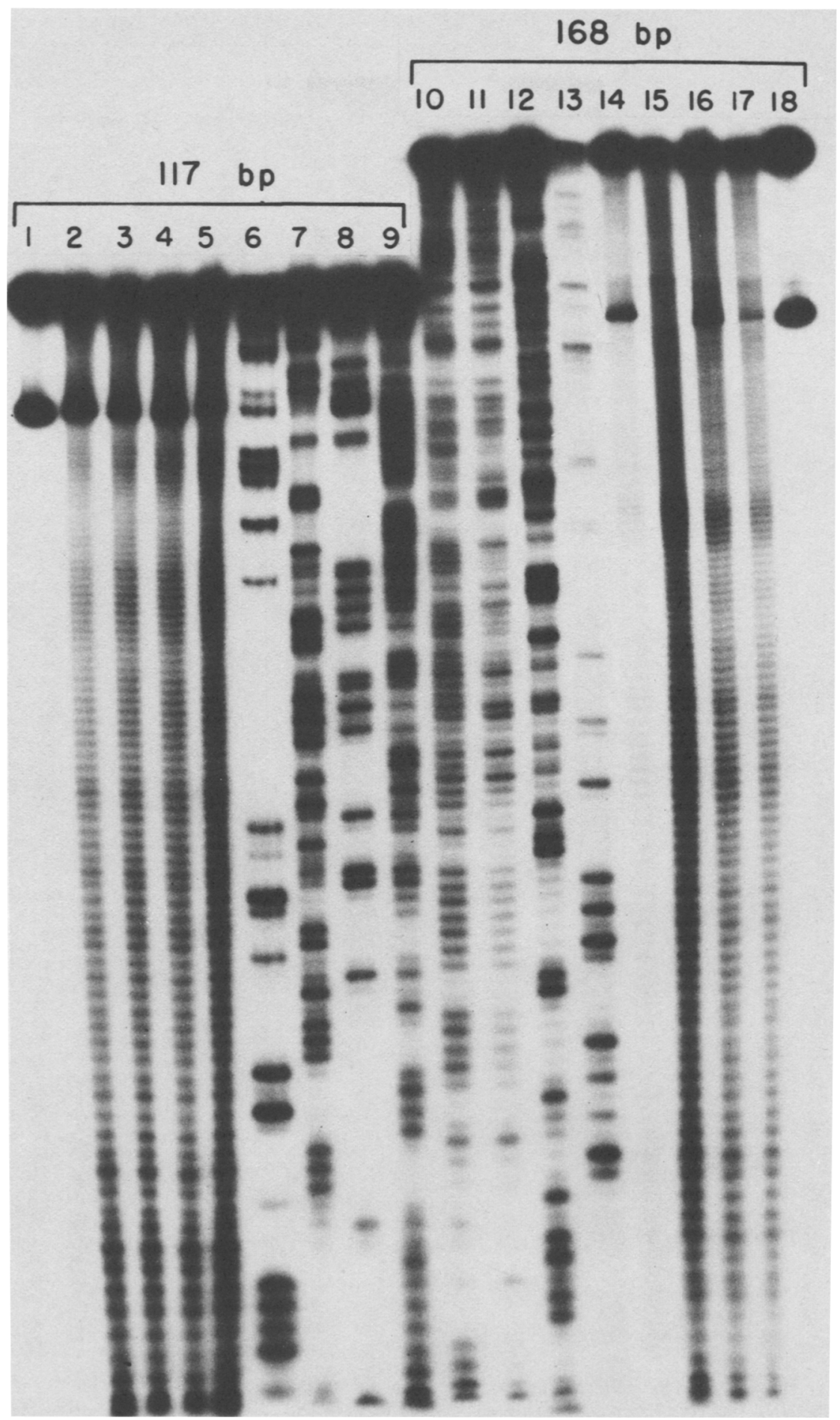

Figure 4. Autoradiograph of sequencing gel of MPE-induced cleavages of DNA. (Lanes I-9) 117-bp DNA fragment. (Lane I) (117-bp DNA standard; (lanes 2-5) reactions contained $200 \mu \mathrm{M}$ DNA, $50 \mu \mathrm{M}$ Fe(II), $4.6 \mathrm{mM}$ DTT, and MPE at 5, 10, 20, and 40 $\mu \mathrm{M}$; (lanes 6-9) Maxam-Gilbert sequencing reactions G, A > C, C , C + T, respectively. (Lanes 10-18) 168-bp DNA fragment; (lanes 10-13) Maxam-Gilbert sequencing reactions $\mathrm{C}+\mathrm{T}, \mathrm{C}, \mathrm{A}>\mathrm{C}$, G, respectively; (lanes $14-17$ ) reactions contained $200 \mu \mathrm{M}$ DNA, $50 \mu \mathrm{M}$ Fe(II), $4.6 \mathrm{~mm}$ DTT, and MPE at 5, 40,20,10 $\mu \mathrm{M}$; (lane 18) 168-bp DNA standard.

\section{MPE·Fe(II) Cleaves DNA Uniformly}

Controls. Several control experiments in the absence of inhibiting drugs were carried out. Lanes 1 and 18 of Figure 4 are the buffered, intact 117-bp and 168-bp DNA fragments ( $200 \mu \mathrm{M}$ in base pairs). The two bands at the top of these control lanes presumably arise from incomplete denaturation. Lanes 2-5 (117-bp fragment) and 14-17 (168-bp fragment) of Figure 4 contain $200 \mu \mathrm{M}$ DNA, $50 \mu \mathrm{M}$ Fe(II), $4.6 \mathrm{~mm}$ DTT, 5-40 $\mu \mathrm{M}$ 


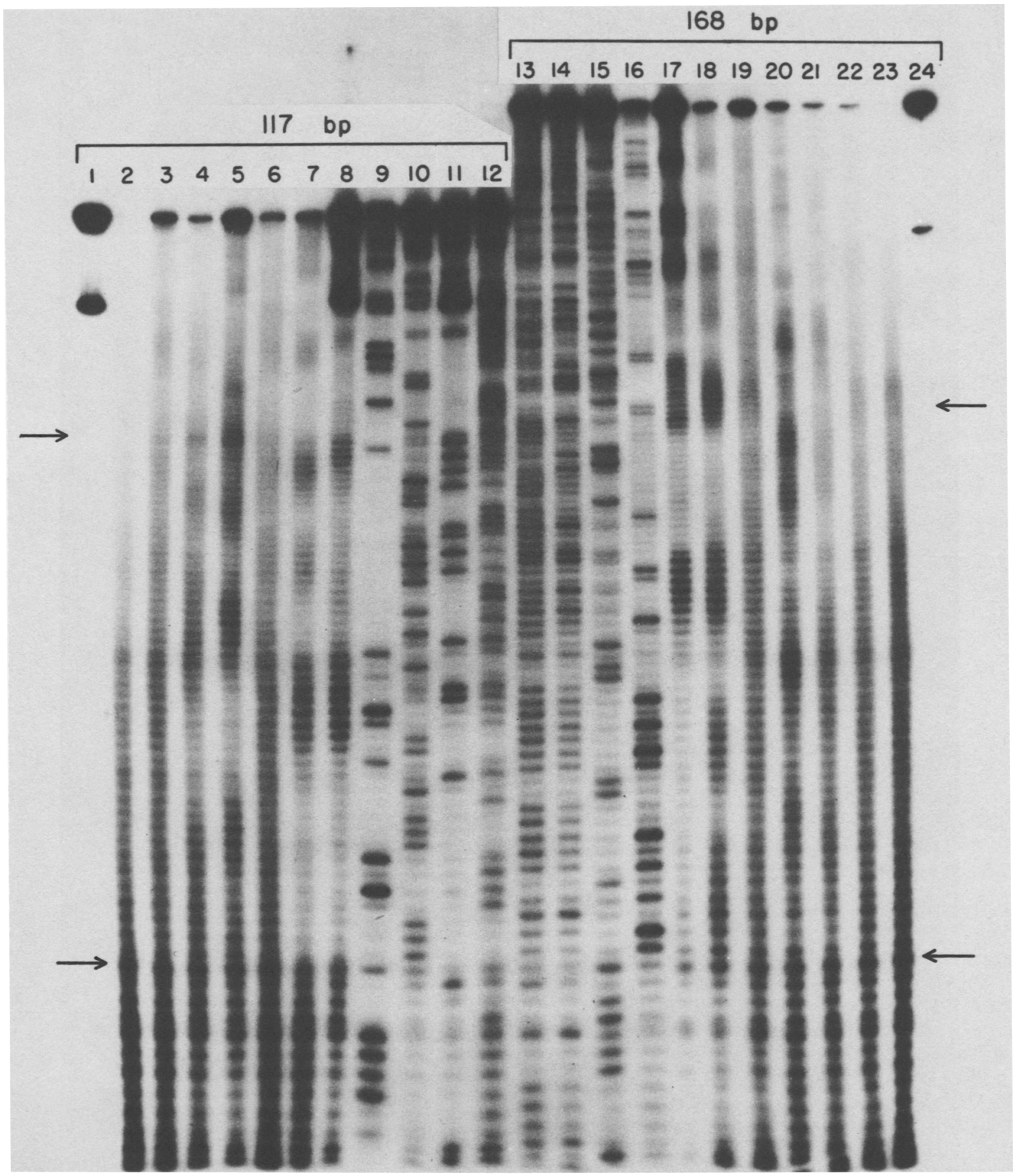

Figure 5. Autoradiograph of sequencing gel depicting footprints for actinomycin D and distamycin A. (Lanes 1-12) 117-bp DNA fragment. (Lane I) 117-bp DNA standard; (lanes 2-8) reactions contained $100 \mu \mathrm{M}$ DNA, $10 \mu \mathrm{M} \mathrm{Fe}(\mathrm{II}), 10 \mu \mathrm{M}$ MPE, and $4 \mathrm{mM}$ DTT; (lane 2) reaction with MPE·Fe(II) and no inhibition drugs; (lanes 3-5) reactions contained actinomycin D at 1, 10, and $100 \mu \mathrm{M}$; (lanes 6-8) reactions contained distamycin $A$ at 1,10 , and $100 \mu \mathrm{M}$; (lanes 9-12) Maxam-Gilbert sequencing reactions G, A $>C, C, C+T$, respectively. (Lanes 13-24) 168-bp DNA fragments. (Lanes 13-16) Maxam-Gilbert sequencing reactions C $+\mathrm{T}, \mathrm{C}, \mathrm{A}>\mathrm{C}$, G, respectively; (lanes 17-23) reactions contained $100 \mu \mathrm{M}$ DNA, $10 \mu \mathrm{M}$ Fe(II), $10 \mu \mathrm{M}$ MPE, 4 mM DTT; (lanes 17-19) reactions contained distamycin A at 100 , 10 , and $1 \mu \mathrm{M}$; (lanes $20-22$ ) reactions contained actinomycin D at 100,10 , and $1 \mu \mathrm{M}$; (lane 23) reaction with MPE $\cdot \mathrm{Fe}(\mathrm{II})$ and no inhibition drug; (lane 24) 168-bp DNA standard.

MPE. Lanes 2-5 and 14-17 depict the relatively uniform cleavage pattern generated by MPE over a broad concentration range. This provides the baseline by which other cleavage patterns are compared. Lanes
6-13 are the products of the Maxam-Gilbert sequencing reactions and are used as markers for base identification.

Lanes 1 and 24 of Figure 5 are the buffered, intact 


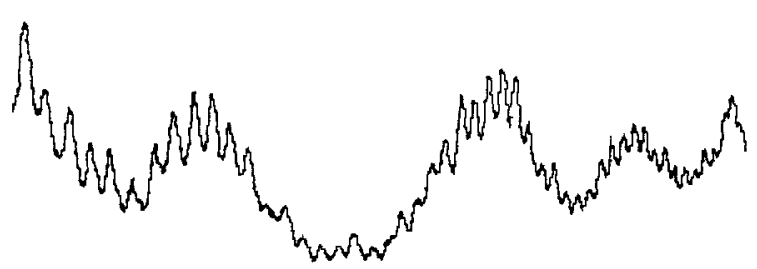

ACTINOMYCIN

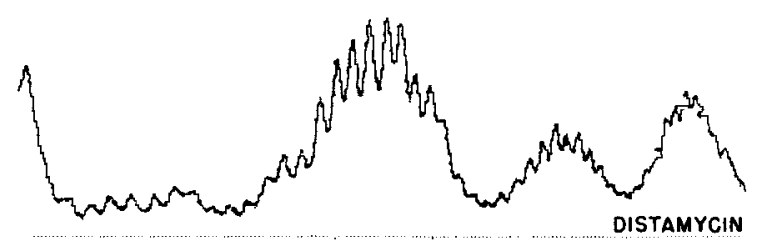

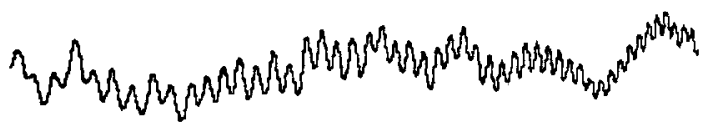

$$
\begin{aligned}
& \text { MPE - Fe(II) CONTROL }
\end{aligned}
$$

Figure 6. Densitometer scan (left to right) of 117-bp DNA fragment (from lower arrow to upper arrow on gel autoradiograph in Fig. 5. (Top) Lane 5, actinomycin at $100 \mu \mathrm{M}$; (middle) lane 7, distamycin at $10 \mu \mathrm{M}$; (bottom) lane 1 , MPE-Fe(II) control. Valleys are regions protected by drugs from MPE•Fe(II) cleavage.

117-bp and 168-bp DNA fragments, respectively (100 $\mu \mathrm{M}$ in base pairs). Lanes 2 (117-bp fragment) and 23 (168-bp fragment) are controls containing $100 \mu \mathrm{M}$ DNA, $10 \mu \mathrm{M} \mathrm{MPE} \cdot \mathrm{Fe}(\mathrm{II})$, and $4 \mathrm{~mm}$ DTT, indicating a uniform cleavage pattern.

Actinomycin. Different concentrations of actinomycin $(1 \mu \mathrm{M}, 10 \mu \mathrm{M}$, and $100 \mu \mathrm{M})$ were allowed to equilibrate with the 117-bp and 168-bp DNA fragments $(100 \mu \mathrm{M} \mathrm{bp})$. To this was added $10 \mu \mathrm{M}$ MPE $\cdot \mathrm{Fe}(\mathrm{II})$ and 4 mM DTT (final concentrations). A series of bands or regions of alternating high and low density on the autoradiograph are observed when MPE·Fe(II)/DTT cleaves DNA in the presence of actinomycin. The highest concentration of actinomycin $\mathrm{D}(100 \mu \mathrm{M})$ shows the sharpest footprinting patterns (Fig. 5, lanes 5 and 20). The densitometer trace allows a measure of the actinomycin blocking of MPE-Fe(II) DNA cleavage on a 50-bp section of the 117-bp and 168-bp restriction fragments (Figs. 6 and 7), which are illustrated as protected regions on opposite strands in Figure 8.

Distamycin. Different concentrations of distamycin ( $1 \mu \mathrm{M}, 10 \mu \mathrm{M}$, and $100 \mu \mathrm{M}$ ) were allowed to equilibrate with the 117-bp and 168-bp DNA fragments (100 $\mu \mathrm{M}$

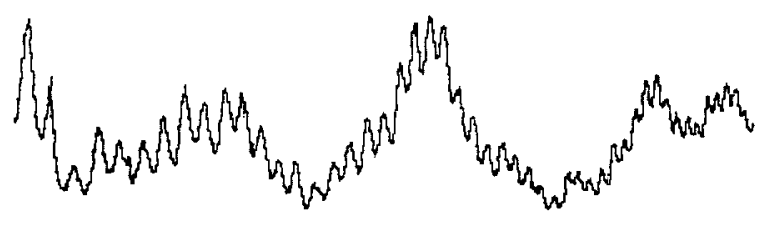

ACTINOMYCIN

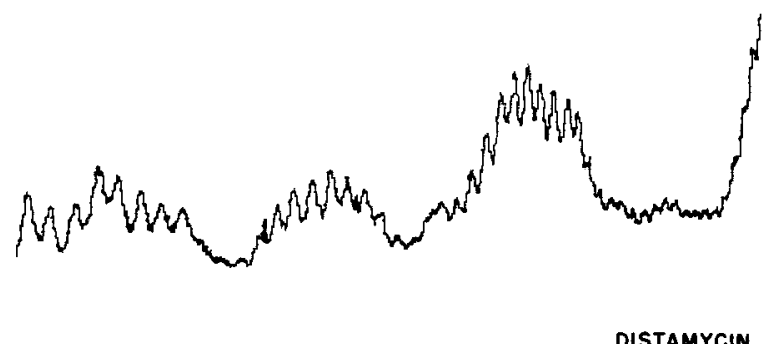

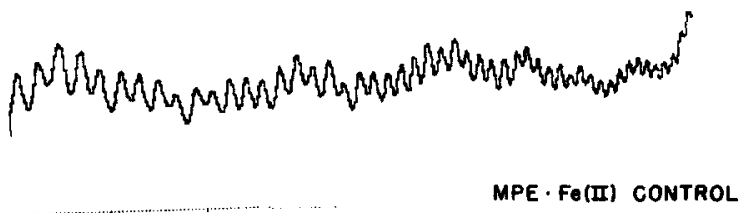

Figure 7. Densitometer scan (left to right) of 168-bp DNA fragment (from lower arrow to upper arrow on gel autoradiograph in Fig. 5). (Top) Lane 20, actinomycin at $100 \mu \mathrm{M}$; (middle) lane 18 , distamycin at $10 \mu \mathrm{M}$; (bottom) lane $23, \mathrm{MPE} \cdot \mathrm{Fe}$ (II) control. Valleys are regions protected by drugs from MPE-Fe(II) cleavage.

bp). To this was added $10 \mu \mathrm{M} \mathrm{MPE} \cdot \mathrm{Fe}(\mathrm{II})$ and $4 \mathrm{mM}$ DTT (final concentrations). Lower concentrations of distamycin $(10 \mu \mathrm{M})$ were sufficient to produce footprints that are well resolved compared with the case of actinomycin. Certain $\mathrm{dA} \cdot \mathrm{dT}$-rich regions that suffered efficient MPE-Fe(II) cleavage in the presence of actinomycin are now protected by distamycin. Inspection of gel-lanes 5 and 7 of Figure 5 (actinomycin and distamycin, respectively) reveals complementary regions $(\mathrm{dG} \cdot \mathrm{dC}$ vs. $\mathrm{dA} \cdot \mathrm{dT}$ rich), resulting from different protection by the two drugs.

\section{DISCUSSION}

\section{Complementary-strand Footprints}

In principle, an altered DNA-cleavage pattern could be the result of suppressed reaction at some sites, enhanced reaction at others, or a combination of both effects. Without ruling out the possibility of enhanced cleavage, we have interpreted the light regions on the autoradiograph as regions of reduced cleavage of DNA
Figure 8. Illustration of drug-protected regions (black areas) for actinomycin, opposite-strand analysis. (Top) 168-bp fragment; (bottom) 117-bp fragment.

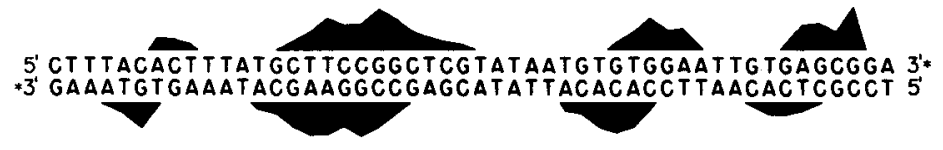




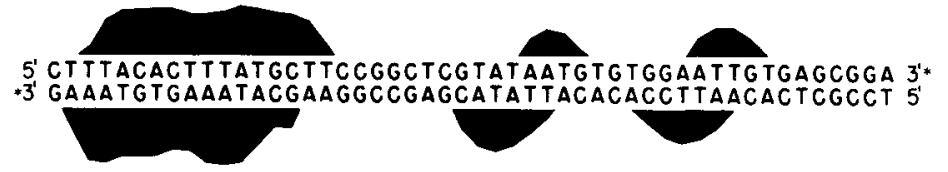

Figure 9. Illustration of drug-protected regions (black areas) for distamycin, opposite-strand analysis. (Top) 168-bp fragment; (bottom) 117-bp fragment. by MPE $\cdot \mathrm{Fe}$ (II) due to the presence of bound drug. The light regions on the autoradiograph (Fig. 5) correspond to the valleys in the densitometer tracings (Figs. 6 and 7 ), which, in turn, correspond to the black regions on opposite strands on the 50-bp sequence shown in Figures 8 and 9.

We can see from complementary-strand analysis that the footprints are asymmetric for both actinomycin and distamycin. The footprints appear to be shifted 1-2 bp to the $3^{\prime}$ side on each strand and 1 bp underprotected on the $5^{\prime}$ side. These data are consistent with the model (Fig. 2). With this knowledge, we can now interpret the footprint and assign the preferred binding sites of actinomycin and distamycin with greater confidence. In addition, single-strand analyses of MPE footprinting of actinomycin and distamycin on other DNA restriction fragments become amenable to interpretation (Van Dyke et al. 1982).

The 50-bp sequence that afforded the complementarystrand analysis is composed of $44 \% \mathrm{dG} \cdot \mathrm{dC}$ and $56 \%$ $\mathrm{dA} \cdot \mathrm{dT}$. We can identify 24 bp protected by the minorgroove binder distamycin out of $50 \mathrm{bp}$, which corresponds to $48 \%$ saturation (Fig. 10). Of the 24 bp protected by distamycin, $20 \mathrm{bp}(83 \%)$ are $\mathrm{dA} \cdot \mathrm{dT}$. The minimum protected region observed is the 4-bp sequence, $5^{\prime}$ AATT $3^{\prime}$. For a binding-site size of $4 \mathrm{bp}$, the binding density (ligand bound/bp) would be 0.12 or six molecules on the 50-bp sequence.

Similarly, we can identify 22 out of 50 bp protected by the intercalator actinomycin, which corresponds to $44 \%$ saturation (Fig. 10). Of the 22 bp protected by actinomycin, 15 bp $(68 \%)$ are $\mathrm{dG} \cdot \mathrm{dC}$. The minimum protected region observed is the 3-bp sequence, 5' GTG 3'. For a binding-site size of 3 or $4 \mathrm{bp}$, the binding density for actinomycin would be $0.15-0.11$ or approximately six to seven molecules on the 50 -bp sequence. It is difficult at this time to determine whether this is a reasonable estimate. Two closely spaced but not contiguous ligands could exclude MPE cleavage between them. Therefore, fewer molecules could appear to provide a larger protected region. Alternatively, one could imagine unsymmetrical ligand binding where the tetherEDTA is able to oxidize the deoxyribose moiety more efficiently on one side of the ligand. In this case a somewhat larger number of bound molecules could afford a smaller protected region than expected.

In summary, complementary-strand analyses of distamycin- and actinomycin-binding sites on DNA support the asymmetric model for MPE·Fe(II) footprinting. The footprints appear to be shifted $1-2$ bp to the $3^{\prime}$ side on each strand and are 1 bp underprotected on the $5^{\prime}$ side. With this model in hand, we expect to define more precisely the binding sites of small molecules on native DNA and to interpret more correctly singlestrand analyses on other DNA restriction fragments.

\section{ACKNOWLEDGMENT}

We are grateful to the National Institutes of Health for grant support (GM-27681) and a National Research Service Award (GM-07616) to M.W.V.

\section{REFERENCES}

Berman, H.M., S. Neidle, C. Zimmer, and H. Thrum. 1979. Netropsin, a DNA-binding oligopeptide structural and binding studies. Biochim. Biophys. Acta 561: 124.

Burger, R.M., J. Peisach, and S.B. Horwitz. 1981. Minireview, mechanism of bleomycin action: In vitro studies. Life Sci. 28: 715.

GoldBerg, I.H., M. RabinowitZ, and E. Reich. 1962. Basis of actinomycin action. I. DNA binding and inhibition of RNA polymerase synthetic reactions by actinomycin. Proc. Natl. Acad. Sci. 48: 2094.

Неснт, S.M. 1979. Bleomycin: Chemical, biochemical and biological aspects. Springer-Verlag, New York.

Hertzberg, R.P. and P.B. Dervan. 1982. Cleavage of double helical DNA by (methidiumpropyl-EDTA)iron (II). $J$. Am. Chem. Soc. 104: 313.

KRUGH, T.R. 1981. Oligonucleotide and polynucleotide-drug complexes in solution as investigated by NMR. In Topics in nucleic acid structure (ed. E. Neidle), p. 197. Macmillan, London.

Krylov, A.S., S.L. Grokhovsky, A.S. Zasedatelev, A.L. ZhUGE, G.V. GuRSKY, and B.P. GotTIKH. 1979. Quantitative estimation of the contribution of pyrrolcarboxamide groups of the antibiotic distamycin A into specificity of its binding to DNA AT pairs. Nucleic Acids Res. 6: 289.

LuCK, G., H. Treibel, M. WAring, and C. Zimmer. 1974. Conformation dependent binding of netropsin and distamycin to DNA and DNA model polymers. Nucleic Acids Res. 1: 503.

MAXAM, A.M. and W. Gilbert. 1980. Sequencing end-

$\begin{array}{cccc}\text { TTTACACTTTATGCT } & \text { ATAAT } & \text { AATT } \\ \text { AAATGTGAAATACGA } & \text { TATTA } & \text { TTAA } \\ \text { CAC } & \text { GCTTCCGGC } & \text { TGTGG } & \text { TGAGC } \\ \text { GTG } & \text { CGAAGGCCG } & \text { ACACC } & \text { ACTCG }\end{array}$

Figure 10. (Top) Preferred distamycin-binding sites; (middle) preferred actinomycin-binding sites; (bottom) 50-bp sequence substrate. 
labeled DNA with base-specific chemical cleavages. Methods Enzymol. 65: 499.

Muller, W. and D.M. Crothers. 1968. Studies of the binding of actinomycin and related compounds to DNA.J. Mol. Biol. 35: 251.

Patel, D.J., S.A. Kozlowski, J.A. Rice, C. Broka, and K. ITAKURA. 1981. Mutual interaction between adjacent $\mathrm{dG} \cdot \mathrm{dC}$ actinomycin binding sites and $\mathrm{dA} \cdot \mathrm{dT}$ netropsin binding sites on the self-complementary d(C-G-C-G-A-AT-T-C-G-C-G) duplex in solution. Proc. Natl. Acad. Sci. 78: 7281 .

SoBELL, H.M. 1973. The stereochemistry of actinomycin binding to DNA and its implications in molecular biology. Prog. Nucleic Acid Res. Mol. Biol. 13: 153.

Takusagawa, F., M. Dabrow, S. Neidle, and H.M. BerMAN. 1982. The structure of a pseudo intercalated complex between actinomycin and the DNA binding sequence $\mathrm{d}(\mathrm{GpC})$. Nature 296: 466.
Tanaka, T. and B. Weisblum. 1974. Construction of a colicin El-R factor composite plasmid in vitro: Means for amplification of deoxyribonucleic acid. J. Bacteriol. 121: 354.

VAn Dyke, M.W., R.P. Hertzberg, and P.B. Dervan. 1982. Map of distamycin, netropsin, and actinomycin binding sites on heterogeneous DNA: DNA cleavage-inhibition patterns with methidium propyl-EDTA-Fe(II). Proc. Natl. Acad. Sci. 79: 5470 .

Wartell, R.M., J.E. Larson, and R.D. Wells. 1974. Netropsin, a specific probe for A-T regions of duplex deoxyribonucleic acid. J. Mol. Biol. 249: 6719.

WELLS, R.D. and J.E. LARSON. 1970. Studies on the binding of actinomycin D to DNA and DNA model polymers. $J$. Mol. Biol. 49: 319.

ZIMMER, C. 1975. Effects of the antibiotics netropsin and distamycin $\mathrm{A}$ on the structure and function of nucleic acids. Prog. Nucleic Acid Res. Mol. Biol. 15: 285. 


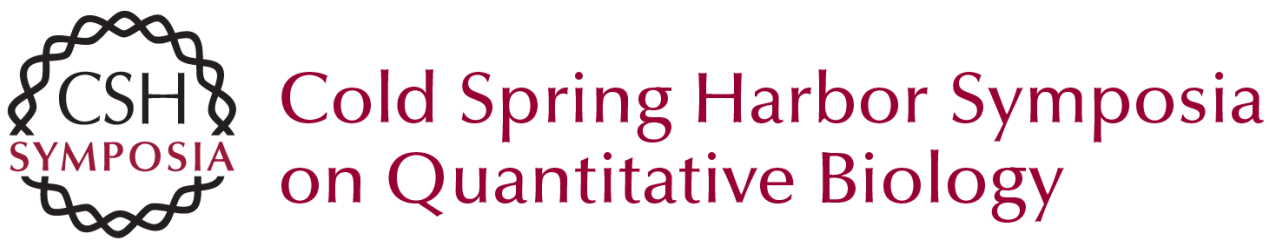

\title{
Footprinting with MPE.Fe(II). Complementary-strand Analyses of Distamycin- and Actinomycin-binding Sites on Heterogeneous DNA
}

\author{
M.W. Van Dyke and P.B. Dervan
}

Cold Spring Harb Symp Quant Biol 1983 47: 347-353

Access the most recent version at doi:10.1101/SQB.1983.047.01.040

References This article cites 16 articles, 5 of which can be accessed free at:

http://symposium.cshlp.org/content/47/347.refs.html

Article cited in:

http://symposium.cshlp.org/content/47/347\#related-urls

Email alerting

Receive free email alerts when new articles cite this article service sign up in the box at the top right corner of the article or click here

To subscribe to Cold Spring Harbor Symposia on Quantitative Biology go to: http://symposium.cshlp.org/subscriptions 